1 Bahir Dar University, Ethiopian Institute of Textile and Fashion Technology, Bahir Dar, 1037, Ethiopia

\title{
Prediction of Psychological Comfort Properties of 100\% Cotton Plain Woven Fabrics made from Yarns with Different Parameters
} Napovedovanje psihološkega udobja 100-odstotnih
bombažnih tkanin v vezavi platno, izdelanih iz prej z različnimi
parametri

Original scientific article/lzvirni znanstveni članek

Received/Prispelo 12-2019• Accepted/Sprejeto 2-2020

\begin{abstract}
The psychological satisfaction of the textile customer is the first criteria used to evaluate clothing and a lack of aesthetics, while fashionability and physical appearance contribute to the psychological discomfort of users. Either inherently or due to processing, cotton cloths demonstrate different psychological comfort behaviours. Manufacturers must therefore produce fabrics with optimum psychological comfort parameters. The objective of this research was to study the effect of cotton yarn parameters on the psychological comfort properties of woven fabrics. Four woven fabrics were produced from cotton yarns with different yarn twists, yarn counts, strengths and yarn elongations. Psychological comfort parameters such as wrinkle, drape, crease, bending modules and flexural rigidity were measured and analysed in accordance with the ES ISO 9867, ISO 9073-9, ES ISO 2313 and ASTM D1388-18 standards, respectively. Multiple regression equations were developed to predict the comfort properties of clothing in relation to yarn parameters. A statistical analysis showed that the wrinkle recovery and drapeability of fabrics were significantly affected by yarn twist, count and tenacity, and the elongation of yarns. However, yarn twist, count, tenacity and elongation had an insignificant effect on the crease recovery of woven samples at an F-value of 3.546 and a P-value of 0.069 . The stiffness properties of the fabrics such as flexural rigidity and bending modules also showed insignificant difference between samples at $\mathrm{F}=38487.969, \mathrm{P}=0.057$ and $\mathrm{F}=25.506, \mathrm{P}=0.055$ respectively. A multiple regression analysis showed a positive correlation between yarn parameters (factors) and response, with Adj. $R^{2}$ of 0.0998 , Adj. $R^{2}$ of 0.975 and Adj. $R^{2}$ of 1 for crease recovery, wrinkle recovery and drape coefficient, respectively. The equations developed are helpful to fabric manufacturers in sourcing yarns with specific parameters to produce the desired comfort level in a fabric.

Keywords: yarn parameters, psychological comfort, cotton fabric, wrinkle, crease recovery, bending modules
\end{abstract}

\section{Izvleček}

Psihološko zadovoljstvo kupca s tekstilijo je prvi kriterij ocenjevanja oblačila, pri čemer pomanjkanje estetike, modnosti in fizičnega videza vplivajo na psihološko neudobje uporabnika oblačila. Bombažna tekstilija izkazuje sama ali zaradi obdelav različne psihološke odzive. Proizvajalci morajo zato izdelovati tekstilije z optimalnimi parametri psihološkega udobja. Namen raziskave je bil preučiti vpliv parametrov bombažne preje na psihološke lastnosti udobja tkanin. Štiri tkanine so bile izdelane iz bombažnih prej z različnim vitjem, dolžinsko maso, trdnostjo in raztezkom. Parametri psihološkega udobja, kot so gube, drapiranje, zmečkanost, upogibni modul in upogibna togost, so bili izmerjeni in analizirani v skladu s standardi ES ISO 9867, ISO 9073-9, ES ISO 2313 in ASTM D1388-18. 
Razvite so bile regresijske enačbe za napovedovanje lastnosti udobnosti oblačil glede na parametre preje. Statistična analiza je pokazala, da so na izravnalne kote in drapiranje tkanin pomembno vplivali vitje, dolžinska masa, trdost in raztezek preje. Našteti parametri pa niso pomembno vplivali na izravnavanje gub (zmečkanin) tkanih vzor$\operatorname{cev}(F=3,546, P=0,069)$. Pri togosti tkanin, in sicer upogibni togosti in upogibnem modulu, med vzorci ni bilo statistično pomembnih razlik ( $F=38487.969, P=0,057 ; F=25.506, P=0,055)$. Večkratna regresijska analiza je pokazala pozitivno korelacijo med parametri preje (faktorji) in odzivom s prilagojenimi korelacijskimi koeficienti $R^{2}=0,0998$ za izravnavanje gub, $R^{2}=0,975$ za izravnalne kote in $R^{2}=1$ za drapiranje. Razvite enačbe so v pomoč proizvajalcem tkanin pri nabavi preje z določenimi parametri za izdelavo tkanin z želenim udobjem.

Ključne besede: parametri preje, psihološko udobje, bombažna tkanina, gube, zravnava gub, upogibni modul

\section{Introduction}

Psychological comfort has received attention from manufacturers in recent years due to consumers' demands for aesthetic value, fashionability and good clothing appearance, as factors considered in the purchase process. To produce a comfortable garment, comfort properties should be considered during manufacturing and garment design [1]. Clothing with poor wrinkle, low drapeability and crease recovery properties will decrease wearers' psychological satisfaction. Natural fibres have better comfort properties than synthetic fibres. Even though they have several advantages, they also have some disadvantages, such as the quick wrinkling of cotton fabric during wear [2]. Yarn parameters are very important in producing suitable fabric with optimised performance for a specific end use. Several researchers have shown that yarn properties affect the properties of clothing. Gong studied cotton fabrics using five control factors in order to examine their effects on yarn cross-sectional shape changes along the yarn path. The factors studied were fibre type, yarn linear density and twist factor, and warp and weft cover factors. The study focused on the cross-sectional structure and its influence on woven fabric [3]. Pattanayak and Luximo pointed out that there are many factors that influence the aesthetic appearance of a fabric and the outstanding effect on the actual beauty of the cloth [4]. Drape is one of the critical factors affecting psychological comfort. The drape or drapeability of a fabric refers to the manner in which the fabric falls, shapes, gathers or flows with gravity on a model form or on a human body. Fabric drape has attracted the attention of many researchers in recent years because of the attempt to create a clothing CAD system by introducing fabric material properties in which drape is the key element [5]. Pattanayak and Luximo stated that fabric drape is an important parameter for the selection and development of textile materials for apparel industries. Predictions of the drape property of cotton woven fabrics were developed using multiple regression methods [4]. Another researcher investigated the improvement of the crease recovery of cotton fabrics. Reactive dyed fabrics were treated with dimethylol dihydroxy ethylene urea (DMDHEU) resin in order to improve their crease recovery characteristics. Two types of treatments were carried out: conventional thermal curing and gamma irradiation. Finally, the effect of treatments on crease recovery, and the mechanical and thermal properties of fabrics were studied. They found that the finishing of cotton fabrics with gamma irradiation demonstrated better crease recovery [6]. The effect of yarn twist has also been studied. It was observed that the crease recovery of cotton fabrics decreases as yarn twist increases [7]. Similarly, Liu et al. investigated the impact of mechanical action on the wrinkling of cotton fabrics in a drum washer [8]. They observed that the spinning speed and wash load were the main factors influencing the smoothness of cotton fabrics. As the wash load increased, the free motion region decreased and the ratio of the passive motion region increased, resulting in the severe wrinkling of cotton fabric.

Hala [9] studied the effect of yarn twist direction on the drapability of fabrics and observed that twist direction does indeed have an effect on drape property. The bending and drape properties of woven fabrics, and the effect of weft density, weft yarn count and warp tension on these properties were also investigated by Süle [10]. It was reported that woven fabrics with thicker weft yarns and higher weft densities had a higher bending rigidity. In addition, the bending rigidities of the fabrics in the warp directions increased as warp tension increased. King and Johnston [11] studied the effect of stiffness, shear, extensibility, thickness and density on the drape coefficient 
of fabrics. A multiple regressions analysis equation was developed to determine drape coefficient based on stiffness, shear, extensibility and density. They concluded that the drapeability characteristics of a fabric are affected, to some extent, by fibre stiffness [12]. Multiple regression models were built based on factors such as bending, shear, tensile, compression and aerial density. It was found that tensile and compression factors have little effect on the drape property of fabrics. It was observed that bending, shear and aerial density affect drape characteristics [2,4]. The effect of yarn parameters on the mechanical properties (at low-stress) of woven fabrics, tensile strength, compression, bending and shear property were studied by the authors of this work [13]. Though many researchers have studied the effect of yarn parameters such as count and twist on tactile comfort, and on drape, tensile and stiffness properties, most of the studies were done at the grey fabric level. The effect of yarn properties on fabric wrinkle resistance have not been thoroughly addressed. The effects of yarn parameters such as yarn count, twist, strength and elongation on the psychological comfort properties of half-bleached woven fabrics were studied in this work. A multiple regression analysis was carried out to predict stiffness, wrinkle recovery, crease recovery and the drape properties of fabrics.

\section{Materials and methods}

\subsection{Materials}

Four types of cotton yarns were manufactured by Bahir Dar Textile S.C. using a C-60 IDF (Integrated Draw frame) machine and a rotor spinning system (RIETER- R 923). The yarns were selected randomly from daily production when the count and twist were changed by spinners on the same machine. All yarns samples were produced from the same fibre mix with a micronaire value of 4.02 , maturity of 0.85 , upper half mean length (UHML) of $30.16 \mathrm{~mm}$, uniformity index (UI) of $83.8 \%$, short fibre content of 6.9 , strength of $29.8 \mathrm{~g} /$ tex, elongation of $7.6 \%$ and trash grade three. Trash grade is known as TrGrd in USTER HVI 1000 machine and this value is measured by the trash module and consist of 1 up to 4 alphanumeric characters. Yarn twist, yarn count, strength and elongation were evaluated according to ASTM D1422, ES ISO 2060 and ES ISO 2062 testing standard methods, respectively, and are shown in Table 1.

A Statimat $\mathrm{Me}+$ instrument was used to evaluate yarn strength and elongation. Table 2 shows the actual thread density and thickness of the fabrics, as well as nominal yarn count and twist. All woven fabrics were produced on the same air jet loom (PICANOL- OMP $800-2-\mathrm{P})$ at a speed of $350 \mathrm{~min}^{-1}$ (350 rpm) by Bahir Dar Textile S.C. Machine speed, warp yarn property, thread density (warp $=20 \mathrm{~cm}^{-1}$ and weft $18 \mathrm{~cm}^{-1}$ ) and fabric structure (plain) were kept constant (see Tables 1 and 2) during fabric production. The only variation was the use of different weft yarns. The produced fabric samples were treated using a halfbleach combined treatment system on a Jigger machine. The fabric and water solution were prepared at a material liquor ratio (MLR) of $1: 5, \mathrm{H}_{2} \mathrm{O}_{2} 4 \%$ of fabric weight, $\mathrm{NaOH} 3 \%$ of fabric weight and $\mathrm{Na}_{2} \mathrm{SiO}_{3}$ $2 \%$ of fabric weight, and a wetting agent of $0.5 \%$ of fabric weight. Each sample was treated at a temperature of $95^{\circ} \mathrm{C}$ for 1.5 hours, with a machine working speed of $40 \mathrm{~m} /$ minute.

\subsection{Test methods}

Specimens were conditioned at a relatively humidity of $(65 \pm 2) \%$ and a temperature of $(20 \pm 1){ }^{\circ} \mathrm{C}$ before each test.

\section{Structural properties}

The structural parameters of the developed fabrics such as thread density and fabric weight were evaluated according to ESISO 7211-2 and ES ISO 3801 test methods, respectively. The nominal thread density

Table 1: Yarn characteristics

\begin{tabular}{|l|c|c|c|c|}
\hline \multicolumn{1}{|c|}{ Yarn code } & Yarn count [tex] & Twist [turns/m] & Tenacity [cN/tex] & Elongation [\%] \\
\hline Y1 & 21.5 & 937.2 & 14 & 6.29 \\
\hline Y2 & 22.9 & 916.7 & 5.74 & 4.43 \\
\hline Y3 & 24.1 & 876.7 & 11.22 & 5.10 \\
\hline Y4 & 36.4 & 843.5 & 8.78 & 5.04 \\
\hline Warp yarn & 20 & 920 & 15 & 6.42 \\
\hline
\end{tabular}


(set at loom) of the fabric and the actual thread density (after manufacturing) are presented in Table 2.

\section{Stiffness test}

Fabric stiffness is the resistance of a fabric to bending. This test measures the bending stiffness of a fabric by allowing a narrow strip of the fabric to bend to a fixed angle under its own weight. The length of the fabric required to bend to this angle is measured and is known as the bending length.

A cantilever stiffness test system is often used as a measure of a fabric's stiffness, as it is an easy test to perform. During testing, a horizontal strip of fabric is clamped at one end and the rest of the strip allowed to hang under its own weight as shown in Figure 1.

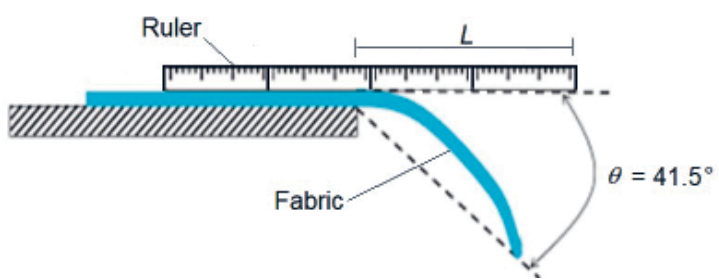

Figure 1: cantilever fabric stiffness test method $L$ - length of projecting fabric, $\Theta$ - angle to which fabric bends, $M$ - fabric mass per unit area

Test specimens measuring $25 \mathrm{~mm}$ in width and 200 $\mathrm{mm}$ in length were cut in a lengthwise direction. Five tests were carried out on each sample in the warp and weft direction according to the ASTM D1388-18 standard. A fabric stiffness analysis, including parameters such as flexural rigidity, bending modulus and bending length, was also performed. The bending length was measured, and the bending modulus and flexural rigidity calculated according to equations 1 and 2 :

$$
\begin{aligned}
& \text { Flexural rigidity }=M C^{3} \\
& \text { Bending modulus }=\frac{G}{\text { Thickness }(\mathrm{mm})}
\end{aligned}
$$

where $M$ is the weight of a fabric in $\mathrm{g} / \mathrm{m}^{2}, C$ is the bending length, $G$ is flexural rigidity and $T$ is fabric thickness.

\section{Drapeability test}

Drape is the degree of fabric deformation when it is allowed to hang freely under its own weight. It is quantitatively expressed as a drape coefficient [11]. The drape coefficient is defined as the percentage of the area of the annular ring of fabric obtained by vertically projecting the shadow of the draped specimen. This test is used as an indication of garment appearance properties when a fabric orients itself into folds in more than one plane under its own weight. In this study, $30 \mathrm{~cm}$ diameter circles samples were used for testing on a Cusick drape tester in order to assess the drape of the fabric. Five tests were carried out on each sample in accordance with the ISO 9073-9 test method. The samples were positioned over a horizontally placed circular rigid disk of 18 centimetres in diameter. The fabric was deformed into a series of folds around the disk. The paper ring containing the shadow image of the draped configuration represents the weight $\left(W_{1}\right)$. The shadow image cut from the paper ring is weighed and marked as $W_{2}$. Finally, the drape coefficient $(D C)$ is calculated using equation 3 :

$D C \%=\frac{W_{2}}{W_{1}} \times 100$

where $W_{2}$ is the mass of the shaded area and $W_{1}$ is the total mass of the paper ring.

\section{Wrinkle property}

Cotton fabric wrinkles easily and is therefore prone to shrinking, which decreases the wearer's psychological acceptance. A wrinkle may be explained as a rhytide, fold, ridge or crease in a cloth or garment. To test the wrinkling behaviour of the samples, their appearance was evaluated after crushing. The fabric sample was crushed and maintained at a specified pressure and time under standard atmospheric conditions in a wrinkle tester. The sample was then removed and its appearance visually compared to a reference sample and rated according to the ES ISO 9867 tests standard.

\section{Crease recovery}

Creasing of a fabric during wear has a significant influence on the wearer's psychological satisfaction an on viewer acceptance. Thus, all clothing must have good crease recovery properties. Crease recovery is the ability of a fabric to return from a collapsed deformed state. In this investigation, crease recovery was measured quantitatively in terms of the crease recovery angle.

Textiles used in clothing must have the ability to crease and fold in order to conform to body shapes, and thus ensure improved comfort during wear. To retain their appearance, however, they must be able 
to eliminate creases that occur in wear and laundering. When a fibre bends, cross-links may break and be formed in a new position, restricting recovery. Otherwise, they will merely stretch and recover when the load is removed. The M003A Shirley crease recovery tester was used for evaluation purposes. For the crease recovery test, $50 \mathrm{~mm} \times 25 \mathrm{~mm}$ rectangular specimens were conditioned at a relative humidity of $65 \pm 2 \%$ and a temperature of $20 \pm 1{ }^{\circ} \mathrm{C}$ for 24 hours then folded for five minutes under a 2-kg load as per the ES ISO 2313 test standard method. This creasing load was then removed and the specimen allowed to recover for another five minutes in the crease recovery tester and the crease recovery angle recorded.

\section{Results and discussion}

\subsection{Structural properties}

As observed in Table 2, the samples had the same fabric structure, thread density and loom settings. Nominal and actual thread densities were slightly different, as shown in Table 2.

\section{Stiffness of fabrics}

Table 3 shows that fabric stiffness, expressed as flexural rigidity and bending modulus, did not change significantly. The effects of yarn count, yarn twist, strength and elongation on woven fabrics were insignificant at an F-value of 38487.969 and Sig-value (Pvalue) of 0.057 on flexural rigidity, and an F-value of

Table 2: Woven fabric characteristics

\begin{tabular}{|c|c|c|c|c|c|}
\hline $\begin{array}{c}\text { Sample } \\
\text { code }\end{array}$ & $\begin{array}{c}\text { Type of } \\
\text { weave }\end{array}$ & $\begin{array}{c}\text { Nominal warp/weft } \\
\text { density [threads/cm] }\end{array}$ & $\begin{array}{c}\text { Actual warp/weft } \\
\text { density [treads/cm] }\end{array}$ & $\begin{array}{c}\text { Thickness } \\
{[\mathrm{cm}]}\end{array}$ & $\begin{array}{c}\text { Mass per unit } \\
\text { area }\left[\mathrm{g} / \mathrm{m}^{2}\right]\end{array}$ \\
\hline F1 & Plain & $26 / 18$ & $27 / 20$ & 0.37 & 168 \\
\hline F2 & Plain & $26 / 18$ & $26 / 17$ & 0.38 & 140 \\
\hline F3 & Plain & $26 / 18$ & $27 / 18$ & 0.35 & 145 \\
\hline F4 & Plain & $26 / 18$ & $26 / 16$ & 0.4 & 160 \\
\hline
\end{tabular}

Table 3: Statistical descriptions of fabric properties

\begin{tabular}{|c|c|c|c|c|c|c|}
\hline \multicolumn{2}{|c|}{ Properties fabrics } & Mean & Std. deviation & Std. error & Minimum & Maximum \\
\hline \multirow{4}{*}{$\begin{array}{l}\text { Crease recovery } \\
\text { of fabrics }\end{array}$} & F1 & 102.6000 & 4.77493 & 2.13542 & 97.00 & 109.00 \\
\hline & $\mathrm{F} 2$ & 99.6000 & 6.18870 & 2.76767 & 95.00 & 110.00 \\
\hline & F3 & 110.6000 & 9.58123 & 4.28486 & 98.00 & 120.00 \\
\hline & $\mathrm{F} 4$ & 111.8000 & 6.97854 & 3.12090 & 104.00 & 120.00 \\
\hline \multirow{4}{*}{$\begin{array}{l}\text { Wrinkle } \\
\text { recovery of } \\
\text { fabrics }\end{array}$} & $\mathrm{F} 1$ & 4.4000 & .54772 & .24495 & 4.00 & 5.00 \\
\hline & F2 & 2.4000 & .54772 & .24495 & 2.00 & 3.00 \\
\hline & F3 & 2.2000 & .44721 & .20000 & 2.00 & 3.00 \\
\hline & F4 & 2.0000 & .00000 & .00000 & 2.00 & 2.00 \\
\hline \multirow{4}{*}{$\begin{array}{l}\text { Drape coefficient } \\
\text { of fabrics }\end{array}$} & $\mathrm{F} 1$ & 73.3220 & .83527 & .37354 & 72.25 & 74.35 \\
\hline & $\mathrm{F} 2$ & 66.1060 & .60455 & .27036 & 65.25 & 66.91 \\
\hline & F3 & 72.7300 & .45645 & .20413 & 72.12 & 73.21 \\
\hline & $\mathrm{F} 4$ & 74.8000 & 1.15972 & .51864 & 73.00 & 76.12 \\
\hline \multirow[t]{4}{*}{ Flexural rigidity } & $\mathrm{F} 1$ & 2014.2000 & 1.78885 & .80000 & 2012.00 & 2016.00 \\
\hline & $\mathrm{F} 2$ & 1398.0000 & 5.70088 & 2.54951 & 1390.00 & 1405.00 \\
\hline & F3 & 1596.6000 & 2.30217 & 1.02956 & 1595.00 & 1600.00 \\
\hline & F4 & 2238.4000 & 5.94138 & 2.65707 & 2230.00 & 2245.00 \\
\hline \multirow{4}{*}{$\begin{array}{l}\text { Bending } \\
\text { modules }\end{array}$} & $\mathrm{F} 1$ & 5439.6000 & 11.32696 & 5.06557 & 5425.00 & 5450.00 \\
\hline & F2 & 3664.4000 & 16.75709 & 7.49400 & 3648.00 & 3684.00 \\
\hline & F3 & 4430.2000 & 813.02380 & 363.59530 & 3680.00 & 5650.00 \\
\hline & F4 & 5636.4000 & 33.42604 & 14.94858 & 5600.00 & 5665.00 \\
\hline
\end{tabular}


25.506 and Sig-value of 0.055 on bending modules. As evident from the statistical analysis, the fabrics made from Y1 (21 tex) to Y4 (36 tex) showed no significant difference in flexural rigidity and bending modulus. This is because fabric flexural properties and handle are primarily influenced by the thickness and density of the fabric. For the tested samples, the two properties shown in Table 2 were not significantly different. Fabric thickness influences bending resistance, or rigidity, and may vary significantly, depending on the structure and texture, while mass per surface area, or GSM, in itself is not an expressive property concerning fabric flexibility in the absence of information on fabric thickness [14].

\section{Drapeability of fabrics}

As evident in Table 5, the produced woven fabrics showed a high significant change in drape coefficient with an F-value of 113.610 and P-value of 0.000 . Drape coefficient is the inverse of drapeability. As mentioned earlier, drape is the extent to which a fabric will distort when it is permitted to droop under its own weight. It is correlated with a fabric's mechanical properties. The most significant factors include bending, shear, formability, fabric weight and thickness. Drape depends on a fabric's parameters, including structure, yarn type and fibre content, as well as finishing treatments [14].

Table 4 shows a multiple linear regression equation of the fabrics' properties. These equations would be useful in predicting crease and wrinkle recovery, as well as the drape coefficient of the fabrics. The adjusted $\mathrm{R}^{2}$ value is an indication of the correlation of yarn properties (factors) and fabric characteristics (responses). When the adjusted $\mathrm{R}^{2}$ value increases or decreases to 1 or -1 , this indicates a strong correlation between them. In this study, the correlation of stiffness and yarn parameters was low (Adj. $\mathrm{R}^{2}=0.231$ for flexural rigidity and $\mathrm{Adj} . \mathrm{R}^{2}=0.125$ for bending modulus). However, crease recovery, wrinkle recovery and the drape coefficient showed a very good correlation with the studied yarn parameters, with values of Adj. $\mathrm{R}^{2}=0.0998$, Adj. $\mathrm{R}^{2}=0.975$ and Adj. $\mathrm{R}^{2}=1$, respectively. The rigidity (high drape coefficient) of woven fabric $F_{1}$ with a coarser count was higher, while fabrics with 36.4 tex had a higher drape coefficient (rigidity) of $74.8 \%$. This indicated that the rigidity of fabrics increased proportionally with an increase in the yarn count (tex). In the case of a coarser count, the number of fibres is high in the yarn cross section and leads to a high drape coefficient, making them less comfortable during wear. Because of its high drape coefficient, the fabric demonstrated less drapeability and flexibility. It was observed that fabric thickness and weight also affected the drapeability of woven fabrics. Fabrics $\mathrm{F}_{2}$ and $\mathrm{F}_{3}$, with a low thickness and low weight, demonstrated a better drapeability of $66.1 \%$ and $72.7 \%$, respectively. A similar concept was also reported in earlier research [14]. Süle reported that woven fabrics with thicker weft yarns and higher weft densities had a higher rigidity [10].

\section{Wrinkle recovery}

The wrinkle recovery of woven fabrics made from four types of yarns with different properties demonstrated a significant change at an F-value of 30.917 and P-value of 0.000 (see Table 5). As the results show, wrinkle recovery was significantly affected by yarn count, twist, elongation and the tenacity of yarns, respectively. A high level of wrinkling was observed in fabric $\mathrm{F}_{4}$ made from a low twist, coarser count, and low elongation and tenacity of yarn. This was because when a load was applied on the fabric, it became compressed and deformed. When the applied load was removed, the tendency to recover to the original position was very low because the structure of low twisted yarns tends to be distorted. The individual correlation of yarn parameters was analysed using linear regression. The results showed that yarn elongation and tenacity were highly correlated to wrinkle recovery at Adj. $\mathrm{R}^{2}$ of 0.928 and $\mathrm{Adj} . \mathrm{R}^{2}$ of 0.924 , respectively. Yarn twist also had good correlation at Adj. $\mathrm{R}^{2}$ of 0.879 , but was low for yarn count at Adj. $\mathrm{R}^{2}$ of 0.596 .

Table 4: Multiple linear regression equation of fabric properties

\begin{tabular}{|l|c|l|}
\hline \multicolumn{1}{|c|}{ Properties } & \multicolumn{1}{|c|}{ Multiple linear regression equation } & \multicolumn{1}{c|}{ Adj. $\mathrm{R}^{2}$} \\
\hline Crease recovery in angle & $169.89411+0.39761 \times \mathrm{X}_{1}-0.06034 \times \mathrm{X}_{2}+2.54839 \times \mathrm{X}_{3}-8.73989 \times \mathrm{X}_{4}$ & 0.998 \\
\hline Wrinkle recovery (grade) & $-22.94906+0.05257 \times \mathrm{X}_{1}+0.02249 \times \mathrm{X}_{2}+0.02214 \times \mathrm{X}_{3}+0.76871 \times \mathrm{X}_{4}$ & 0.975 \\
\hline Drape coefficient & $86.12092+0.22059 \times \mathrm{X}_{1}-0.03755 \times \mathrm{X}_{2}+0.7464 \times \mathrm{X}_{3}+1.14481 \times \mathrm{X}_{4}$ & 1 \\
\hline
\end{tabular}

$\mathrm{X}_{1}=$ yarn count, $\mathrm{X}_{2}=$ yarn twist, $\mathrm{X}_{3}=$ tenacity, $\mathrm{X}_{4}=$ elongation 


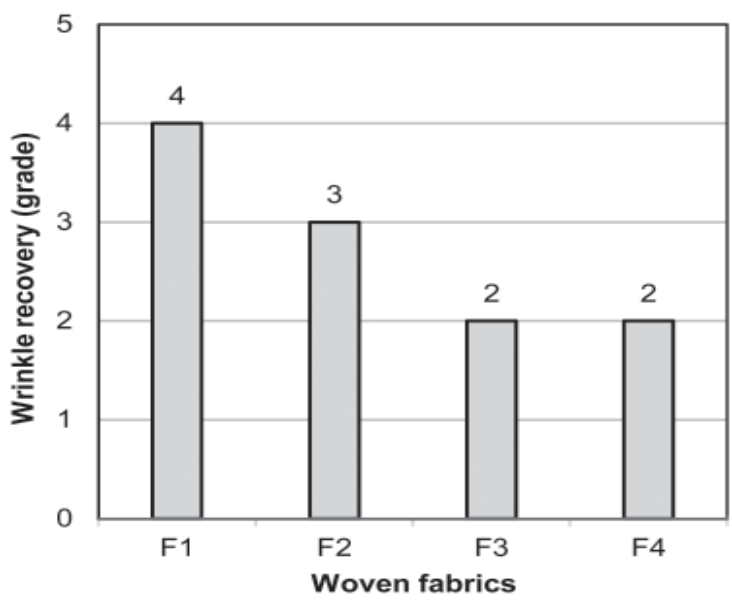

Figure 2: Wrinkle recovery

Figure 2 shows the average grade of wrinkle recovery of developed fabrics. Grade 4 mean very good wrinkle recovery, grade 3 means moderate recovery, grade 2 means low recovery or high wrinkling and grade 1 means poor recovery (formation of extreme wrinkles). The wrinkle recovery grade was thus reduced from fabric $\mathrm{F}_{1}, \mathrm{~F}_{2}, \mathrm{~F}_{3}$ to $\mathrm{F}_{4}$, respectively. This indicated that fabrics $\mathrm{F}_{3}$ and $\mathrm{F}_{4}$ with less twist yarns demonstrated poor recovery due to loose yarns in the fabric, which are easily damaged when a load is applied and the tendency of recovery to the original position is lower. However, woven fabric $F_{1}$ with a higher yarn twist and fine count demonstrated very good wrinkle recovery. This is because of the higher number of turns per meter, which contributes to resistance to the applied load (undamaged) and easier recovery. This result is confirmed by a previous similar report on the recoverability of knitted fabrics [15] and the bending properties of woven fabrics [13].

\section{Crease recovery}

As evident in Table 5, the four types of woven fabrics made from yarns with different properties demonstrated no significant change in terms of the statistical value of the F-value of 3.546 and P-value of 0.069 . A P-value is $\geq 0.05$ indicates that there is no difference between samples. As seen in Figure 3, the crease recovery of the $F_{3}$ and $F_{4}$ samples seems to have greater value. However, that value was statistically insignificant. To predict the crease recovery of fabrics, a multiple regression equation was developed and is presented in Table 4. All factors together had an Adj. $R^{2}$ of 0.998. In addition, linear regression was also performed to show the relation of a single factor and response (crease recovery). Yarn twist (Adj. $\mathrm{R}^{2}$ of 0.991) elongation (Adj. $\mathrm{R}^{2}$ of 0.973), yarn count (Adj. $R^{2}$ of 0.955 ) and tenacity of yarn (Adj. $\mathrm{R}^{2}$ of 0.854 ) were correlated with the crease recovery of fabrics. The Adj. $\mathrm{R}^{2}$ value was used to analyse individual factors, while the remaining yarn parameters were taken as constants.

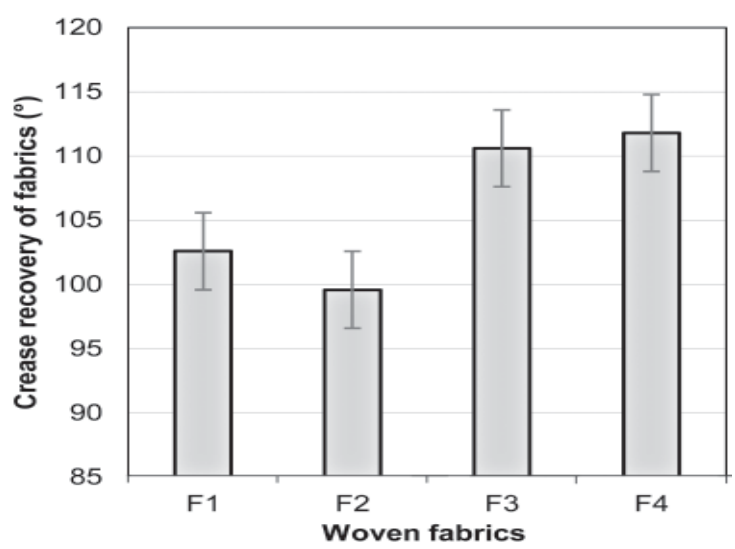

Figure 3: Crease recovery of fabrics

Table 5: Analysis of variance of fabric properties

\begin{tabular}{|l|l|r|r|r|r|c|}
\hline \multicolumn{2}{|c|}{ Properties Fabrics } & Sum of squares & $\mathrm{df}$ & Mean square & \multicolumn{1}{c|}{ F } & Sig. \\
\hline \multirow{3}{*}{ Crease recovery } & Between groups & 536.150 & 3 & 178.717 & 3.546 & 0.069 \\
\cline { 2 - 7 } & Within groups & 806.400 & 16 & 50.400 & & \\
\hline \multirow{3}{*}{ Wrinkle recovery } & Between groups & 18.550 & 3 & 6.183 & 30.917 & 0.000 \\
\cline { 2 - 7 } & Within groups & 3.200 & 16 & 0.200 & & \\
\hline Flexural rigidity & Between groups & 222.942 & 3 & 74.314 & 113.610 & 0.000 \\
\cline { 2 - 7 } & Within groups & 10.466 & 16 & 0.654 & & \\
\hline & Within groups & 3202474.000 & 3 & 734158.000 & 38487.969 & 0.057 \\
\hline \multirow{2}{*}{ Bending modules } & Between groups & 12673882.150 & 3 & 4224627.383 & 25.506 & 0.055 \\
\cline { 2 - 7 } & Within groups & 2650136.400 & 16 & 165633.525 & & \\
\hline
\end{tabular}




\section{Conclusion}

In this study, four types of woven fabrics were produced from yarns with different properties by varying the weft yarn count, twist, strength and elongation. In all woven fabrics, the same warp yarn properties were applied, with the only variation in weft direction due to different weft yarn properties. The effect of these yarn properties on the psychological comfort of woven fabrics was studied and analysed statistically. To predict the value of crease recovery, wrinkle and the drape coefficient of fabrics, an equation was developed using multiple regression. A statistical analysis showed that yarn twist, count, tenacity and elongation demonstrated insignificant changes at an F-value of 3.546 and Sig-value (P-value) of 0.069 on the crease recovery of fabrics. The stiffness of fabrics, expressed as flexural rigidity and bending modulus, also showed an insignificant difference between the samples at an F-value of 38487.969, Sig-value of 0.057 and an F-value of 25.506, Sig-value of 0.055 , respectively. However, the wrinkle properties and drapeability of fabrics were significantly affected by yarn twist, count, tenacity and elongation. Woven fabrics $\mathrm{F}_{3}$ and $\mathrm{F}_{4}$ with less twist yarns had poor recovery properties due to loose yarns in the fabric, which were easily damaged when loaded, while woven fabric $\mathrm{F}_{1}$ with a higher yarn twist $\left(937.4 \mathrm{~m}^{-1}\right)$ and fine count (21.5 tex) had very good wrinkle recovery properties. Due to a coarser yarn count, a high drape coefficient (poor drapeability) was observed because the number of fibres is high in the yarn cross section, thus making them less comfortable.

\section{References}

1. JEVŠNIK, S., YI, L., HU, J., XIAO, H., XINXING, W., PRIMENTAS, A. Thermal-mechanical sensory properties of hot-air welded textile transmission lines. Tekstilec, 2016, 59(2), 126131, doi: 10.14502/Tekstilec2016.59.126-131.

2. XIAO, H.F., YAN, K.L., JI, B.L. Improvement of anti-wrinkle properties of cotton fabrics treated with additives of neutral salts. Fibers Polym., 2018, 19(7), 1576-1583, doi: 10.1007/s12221018-7954-0.

3. GONG, R.H., OZGEN, B., SOLEIMANI, M. Modeling of yarn cross-section in plain woven fabric. Text. Res. J., 2009, 79(11), 1014-1020, doi: $10.1177 / 0040517508101799$.

4. PATTANAYAK, A.K., LUXIMON, A., KHANDUAL, A. Prediction of drape profile of cotton wo- ven fabrics using artificial neural network and multiple regression method. Text. Res. J., 2011, 81(6), 559-566, doi: 10.1177/0040517510380783.

5. HU, J.L., CHAN, Y.F. Effect of fabric mechanical properties on drape. Text. Res. J., 1998, 68(1), 57-64, doi: 10.1177/004051759806800107.

6. HASSAN, M.S. Crease recovery properties of cotton fabrics modified by urea resins under the effect of gamma irradiation. Radiat. Phys. Chem., 2009, 78(5), 333-337, doi: 10.1016/j. radphyschem.2009.01.009.

7. STEELE, R. The effect of yarn twist on fabric crease recovery. Text. Res. J., 1956, 26(10), 739744, doi: 10.1177/004051755602601001.

8. LIU, H., GONG, H., XU, P., DING, X., WU, X., The mechanism of wrinkling of cotton fabric in a front-loading washer : the effect of mechanical action. Text. Res. J., 2019, 89(18), 3802-3810, doi: $10.1177 / 0040517518821909$.

9. AL-GAADI, B., GOKTEPE, F., HALASZ, M.A new method in fabric drape measurement and analysis of the drape formation process. Text. Res. J., 2012, 82(5), 502-512, 10.1177/0040517511420760.

10. SÜLE, G. Investigation of bending and drape properties of woven fabrics and the effects of fabric constructional parameters and warp tension on these properties. Text. Res. J., 2012, 82(8), 810-819, doi: $10.1177 / 0040517511433152$.

11. GAUCHER, M.L., KING, M.W., JOHNSTON, B. Predicting the drape coefficient of knitted fabrics. Text. Res. J., 1983, 53(5), 297-303, doi: $10.1177 / 004051758305300506$.

12. RUPPENICKER, G.F., BROWN, J.J. Properties of fabrics produced from three extra long staple cottons. Text. Res. J., 1959, 29(7), 567-573, doi: $10.1177 / 004051755902900707$.

13. ATALIE, D., FEREDE, A., ROTICH, G.K. Effect of weft yarn twist level on mechanical and sensorial comfort of $100 \%$ woven cotton fabrics. Fash. Text., 2019, 6(3), 1-12, doi: 10.1186/ s40691-018-0169-6.

14. OMEROGLU, S., KARACA, E., BECERIR, B. Comparison of bending, drapability and crease recovery behaviors of woven fabrics produced from polyester fibers having different cross-sectional shapes. Text. Res. J., 2010, 80(12), 1180-1190, doi: 10.1177/0040517509355351.

15. ATALIE, D., GIDEON, R. K., FEREDE, A., TESINOVA, P., LENFELDOVA, I. Tactile comfort and low-stress mechanical properties of halfbleached knitted fabrics made from cotton yarns with different parameters. J. Nat. Fibers, in press, 1-13, doi: 10.1080/15440478.2019.1697989. 